University of Nebraska - Lincoln

DigitalCommons@University of Nebraska - Lincoln

Faculty Publications: Department of Entomology

1994

\title{
Rice Pests in the Ivory Coast, West Africa: Farmers' Perceptions and Management Strategies
}

\author{
A. A. Adesina \\ West Africa Rice Development Association \\ D. E. Johnson \\ West Africa Rice Development Association
}

E. A. Heinrichs

West Africa Rice Development Association, eheinrichs2@unl.edu

Follow this and additional works at: https://digitalcommons.unl.edu/entomologyfacpub

Part of the Agriculture Commons, and the Entomology Commons

Adesina, A. A.; Johnson, D. E.; and Heinrichs, E. A., "Rice Pests in the Ivory Coast, West Africa: Farmers' Perceptions and Management Strategies" (1994). Faculty Publications: Department of Entomology. 843. https://digitalcommons.unl.edu/entomologyfacpub/843

This Article is brought to you for free and open access by the Entomology, Department of at DigitalCommons@University of Nebraska - Lincoln. It has been accepted for inclusion in Faculty Publications: Department of Entomology by an authorized administrator of DigitalCommons@University of Nebraska - Lincoln. 


\title{
Rice Pests in the Ivory Coast, West Africa: Farmers' Perceptions and Management Strategies
}

\author{
A. A. Adesina, D. E. Johnson, ${ }^{1}$ and E. A. Heinrichs
}

West Africa Rice Development Association, BP 2551, Bouaké, Ivory Coast

\begin{abstract}
An understanding of farmers' perceptions of pests and their existing pest control methods can make an important contribution to the development of effective integrated pest management strategies. While the relatively successful rice IPM technologies in Asia have been extensively documented in studies examining farmers' pest perceptions and management practices, studies examining, specifically, perceptions and management practices of West African rice farmers are rare. This may reflect the more limited success to date in the implementation of rice IPM strategies in the region. This paper describes rice pests, pest perceptions, and management practices of smallholder rice farmers in the Ivory Coast. It was found that the major rice pests, as perceived by farmers, are weeds, vertebrates (birds and rodents), and insects. Farmers are generally unable to diagnose rice plant diseases and thus did not consider them as important production constraints. Implications are derived for an integrated pest management strategy that incorporates farmers' perceptions and builds on their existing cultural control practices.
\end{abstract}

Keywords: farmers' perceptions, rice pests, management practices, Ivory Coast

\section{Introduction}

A first step toward the development of successful IPM strategies adapted to farmers' realities is an understanding of farmers' perception of pests, existing control methods, and costs and efficiency of control methods (Heong and Ho, 1987; Hussein, 1987; Schulten, 1989). However, while there are strong arguments to build IPM strategies on the indigenous knowledge base of farmers (Warren, 1989), gaps have been known to exist in farmers' indigenous knowledge of pest biology and ecology (Bentley, 1992, Riches, et al., 1993). 
Therefore, studies of farmers' knowledge should examine how pests are perceived as well as identify gaps in their knowledge and important areas where natural scientists and extension agents could provide critical input to assist farmers. It is important for social and natural scientists to work closely together in order to understand farmers' pest perceptions, enhance their pest identification and management skills, and identify farm-level constraints to adoption of alternative IPM component technologies (Mumford and Norton, 1984; Conelly, 1987; Goldman, 1987; Prah and Okeyo, 1989).

The importance attached to a better understanding of farmers' pest perceptions and management strategies led to the recent organization of two major conferences on the topic (Tait and Napompeth, 1987; Zethner, 1989). These conferences revealed that while the relatively successful development of IPM technologies for rice farmers in Asia (Schulten, 1989) has been extensively documented by farm-level research on pest perceptions and management strategies (Litsinger et al., 1982; Heong, 1984; Heong and Ho, 1987; Hussein, 1987; Kenmore et al., 1987), similar studies of rice farmers in West Africa are rare. This may reffect the limited success to date in the implementation of IPM strategies for rice in West Africa. Past research on farmers' management practices in West Africa make only tangential reference to rice pests (Atteh, 1984). The objective of this paper, therefore, is to describe rice pests, pest perceptions, and management practices of rice farmers in the Ivory Coast. The paper is based on a multidisciplinary village-level survey of 178 rice farmers in three major agro-ecological zones of the Ivory Coast.

\section{Materials and methods}

Rice production in the Ivory Coast is dominated by smallholder subsistence farmers and is found in all the regions of the country. Rice production systems are diverse, varying largely as a function of local agro-ecology, soils, hydrology, ethnicity, gender, and economic factors. The major production systems have been characterized and classified in detail (Becker and Diallo, 1992). In the forest zone, which accounts for approximately twothirds of the national rice area, upland rice systems predominate with rice often being grown with a maize intercrop or relay cropped with cassava. In the savannah zone, the predominant upland rice systems involve rice-maize and rice-yams rotations, or rice intercropped with sorghum or maize. Lowland rice ecosystems are also important in each of these zones.

Three zones (where the West Africa Rice Development Association (WARDA) has ongoing village-level studies), located in the humid-forest, forest-savannah transition and savannah agro-ecologies (Table 1) were selected as representative of the major rice agroecosystems in the Ivory Coast (Becker and Diallo, 1992). Surveys were conducted in 1992 in these villages and relied on two complementary approaches: (1) multidisciplinary field visits focused on informal discussions with farmers in their fields (individually and in groups) during the crop season, and (2) questionnaires following the informal interviews with farmers. Field trips to farmers' fields were undertaken by the WARDA economist, entomologist, and weed scientist. Surveys were conducted in local languages, relying on field staff indigenous to the study zones. A total of 178 farmers were interviewed in these villages. Data were collected on farmers' perception of rice pests, cultural control methods, 
and pesticide use. Farmers indicated and described pests by using local names. These were verified by direct field observations.

\begin{tabular}{|c|c|c|c|c|}
\hline Site & Ecological zone & Latitude & Rainfall ${ }^{a}(\mathrm{~mm})$ & Rainfall distribution \\
\hline Gagnoa & Humid-forest & $6^{\circ} 10^{\prime} \mathrm{N}$ & 1489 & Bimodal \\
\hline Touba & Forest-savannah & $8^{\circ} 20^{\prime} \mathrm{N}$ & 1406 & Mono-modal \\
\hline Boundiali & Savannah & $9^{\circ} 30^{\prime} \mathrm{N}$ & 1433 & Mono-modal \\
\hline
\end{tabular}

a. Girard et al. (1971)

\section{Results}

Farmers considered that the major pests of rice were: weeds (mentioned by $100 \%$ of farmers as being important), birds $(84 \%)$, rodents $(60 \%)$, insects $(40 \%)$, and diseases $(9 \%)$. There were differences between agro-ecological zones (Table 2). Birds were cited more frequently in the humid-forest and forest-savannah transition zone (98\% of farmers) compared with the savannah zone (53\%). Rodents were mostly cited in the humid-forest and forest-savannah zones, by $88 \%$ and $87 \%$ of farmers, respectively, compared with the savannah zone $(2 \%)$. Insects were cited most often in the forest-savannah zone $(60 \%)$ compared with the humidforest $(48 \%)$ and savannah (12\%) zones. Diseases were reported almost exclusively in the humid-forest zone (23\%). Weeds were cited as a problem by all the farmers in each of the three zones. The views of the farmers confirm results of a survey conducted within 23 upland rice-producing countries, which concluded that weeds were the most important biological constraint (Arraudeau and Harahap, 1986). Akobundu and Fagade (1978) also reported that losses caused by uncontrolled weed growth in West Africa could result in yield losses of between 28 and $100 \%$.

Table 2. Percentage of farmers ${ }^{a}$ citing various pests as problems in rice production in three agroecological zones of the Ivory Coast, 1992

\begin{tabular}{lcccc}
\hline & \multicolumn{3}{c}{ Ago-ecological zone } & All \\
\cline { 2 - 4 } & Humid-forest & Forest-savannah & Savannah & 100 \\
Weeds & 100 & 100 & 100 & 84 \\
Birds & 98 & 98 & 53 & 60 \\
Rodents & 88 & 87 & 2 & 40 \\
Insects & 48 & 60 & 12 & 9 \\
Diseases & 23 & 3 & - & \\
\hline
\end{tabular}

a. Number of farmers $=60$ in Gagnoa and Touba, respectively, and 58 in Boundiali.

\subsection{Weeds}

Fifty-three weed species were cited by farmers as infesting their upland and lowland rice fields. The majority of the species cited were weeds of the upland and hydromorphic areas, reflecting the diversity of the weed flora in these ecosystems and their importance as constraints to rice production. In the humid-forest zone, the most widely reported weed 
was the annual grass Panicum laxum, which was reported by all farmers, followed by Chromolaena odorata, Centrosema pubescens, and Scleria sp. (Table 3). The vigorous regrowth from the cut stumps of $C$. odorata requires significant labor for early weeding; $C$. pubescens is also very problematic as it rapidly entangles the young rice plant, making hand weeding difficult. In the forest-savannah transition zone, the major weed was Imperata cylindrica, followed by Ageratum conyzoides and Paspalum scrobiculatum. The most commonly cited weeds in the savannah zone were Echinochloa colona, Rottboellia cochinchinensis, A. conyzoides, and Euphorbia heterophylla. Farmers noted that E. colona is difficult to distinguish from the young rice plants in the early stages of growth, and it is thus often missed during the first weeding, and that irritating hairs on the stems of $R$. cochinchinensis make hand-pulling difficult. Because of their rapid growth, $A$. conyzoides and E. heterophylla are capable of forming a dense canopy if left unchecked.

Table 3. Principal weed species of rice fields, as cited by farmers. Percentage of farmers in each ecological zone, Ivory Coast, 1992

\begin{tabular}{|c|c|c|c|}
\hline & \multicolumn{3}{|c|}{ Agro-ecological zone } \\
\hline & Humid-forest & Forest-savannah & Savannah \\
\hline Panicum laxuma & 100 & - & - \\
\hline Chromolaena odorata ${ }^{\mathrm{a}}$ & 68 & - & - \\
\hline Centrosema pubescens & 42 & - & - \\
\hline Scleria sp. & 32 & - & - \\
\hline Fimbristylis spp. ${ }^{\mathrm{a}}$ & 20 & 2 & 2 \\
\hline Ageratum conyzoides ${ }^{\mathrm{a}}$ & 2 & 62 & 26 \\
\hline Imperata cylindrica ${ }^{a}$ & - & 72 & 14 \\
\hline Paspalum scrobiculatum & - & 37 & 10 \\
\hline Digitaria horizontalis ${ }^{\mathrm{a}}$ & - & 33 & 2 \\
\hline Rottboellia cochinchinensis ${ }^{\mathrm{a}}$ & 7 & 30 & 45 \\
\hline Echinochloa colona ${ }^{\mathrm{a}}$ & - & 5 & 50 \\
\hline Commelina spp. & 3 & 22 & 3 \\
\hline Euphorbia heterophylla & 2 & 3 & 22 \\
\hline $\begin{array}{l}\text { Oryza spp. } \\
(\text { O. barthii/O. longistaminata) }\end{array}$ & - & - & 21 \\
\hline Pennisetum subangustum & - & 20 & 3 \\
\hline
\end{tabular}

a. Weed species farmers regard as becoming increasingly serious.

Across the agro-ecological zones, farmers considered weeds to be most serious at 30 and 60 days after seeding the rice crop. When asked to indicate the weeds that are increasing in importance over time, some distinct patterns were observed across the agro-ecological zones (Table 3). Farmers in the humid-forest zone identified P. laxum and C. odorata as becoming increasingly troublesome. In the forest-savannah and savannah zones, farmers cited mostly A. conyzoides, E. colona, I. cylindrica, E. heterophylla, and R. cochinchinensis.

Of the principal weeds cited by farmers, the majority were cited in the inventories of Akobundu and Fagade (1978) and Merlier (1974), and noted by the latter as being either invasive or difficult to control. However, two species are notably absent from Merlier's list, 
E. heterophylla and C. odorata, both of which have risen to problem status in recent years, and were listed in the more recent inventory of Marnotte (1984). E. heterophylla began to cause serious weed control problems by the end of the 1970s (Diallo, 1981), and C. odorata invaded the humid-forest region in the early to mid-1970s (Delabarre, 1977); both are now widely established. Rouw (1991) showed that if upland rice was grown in the forest zone for three consecutive years after clearing the forest, the crop was overwhelmed by weed growth, including mainly P. laxum and C. odorata. Although the parasitic weeds Striga asiatica, S. aspera, and S. hermonthica have been reported as affecting rice in the savannah zone of the Ivory Coast (Marnotte, 1984; Riches, 1992), these were not mentioned by the farmers surveyed. This could possibly be because our survey in the savannah zone covered only the Boundiali area and the weeds have only localized occurrence in the northern part of the Ivory Coast.

\subsubsection{Beneficial weeds}

Nineteen percent of farmers considered certain weed species as beneficial, including Solanum nigrum, C. odorata, and Hibiscus sp. Advantages cited by farmers were their use as a food or medicine, or ability to suppress other weeds. Some farmers indicated that an infusion of the leaves of $C$. odorata could be used for malaria control and that the leaves could be used for controlling bleeding from a wound. Other farmers indicated that $C$. odorata may improve soil fertility because of the high amounts of leaf litter produced, and that its rapid growth controls the more problematic grass weeds.

\subsubsection{Reasons for not weeding plots}

Many farmers (i.e., 53\%) indicated that periodically they do not weed part or all of their rice fields. Of these farmers, almost two-thirds said that this was the case when weed infestations may become so severe that weeding is unlikely to be worthwhile. Fields were also not weeded because of low levels of weed infestation ( $31 \%$ of farmers), lack of cash to hire labor $(27 \%)$, sickness (24\%), and lack of available labor (15\%). Almost $80 \%$ of the farmers said that if weeds were less problematic they would increase the area of rice they cultivated. More than $90 \%$ of the farmers reported that weeds influenced the choice of rice land, and $65 \%$ of these felt that increasing weed populations was related to poor soil, and $33 \%$ of those in the forest zone said it was related to short fallow.

\subsubsection{Weed control methods}

The most often reported weed management practices include long fallow periods between crops, soil tillage, and early sowing of rice after rains (Table 4). In the humid-forest zone, tillage was common among farmers cultivating lowland areas, while in the savannah zones tillage is practiced both in the upland and lowland areas. Hand pulling of weeds and the use of hoes were the most frequently cited methods of weeding $(62 \%)$, while $24 \%$ of farmers used these in combination with herbicides. Of the farmers surveyed, $42 \%$ reported the use of herbicides on rice, but only $2 \%$ of farmers relied exclusively on herbicides. The major reasons given for herbicide use include greater efficiency for weed control, labor saving, it allows expansion of cultivated area, and makes second weeding more rapid. Reasons ${ }^{2}$ given for not using herbicides were (in decreasing order of importance): a lack of funds 
(53\%), high costs of herbicides (21\%), attachment to traditional methods of weed control $(16 \%)$, ignorance of herbicides $(11 \%)$, and nonavailability of herbicides at the period needed $(9 \%)$.

Table 4. Weed management strategy and control measures used by farmers in the Ivory Coast in each agroecological zone. Percentage of farmers in each zone using a particular method

\begin{tabular}{lccc}
\hline & \multicolumn{3}{c}{ Agro-ecological zone } \\
\cline { 2 - 4 } & Humid-forest & Forest-savannah & Savannah \\
\hline Hand pulling of weeds in rice & 98 & 62 & 95 \\
Hand hoeing of weeds in rice & 68 & 92 & 90 \\
Long fallow period & 78 & 97 & 31 \\
Soil tillage before sowing/planting & 42 & 50 & 52 \\
Use of herbicides & 30 & 30 & 55 \\
Early sowing of rice & 30 & 2 & 10 \\
\hline
\end{tabular}

\subsection{Vertebrate pests}

\subsubsection{Birds}

Birds are major problems for farmers at different stages of rice crop growth ranging from sowing to "milk stage" and maturity. The most common bird pests during the "milk stage" are Lonchura spp. and Quelea erythrops, whereas at maturity, the most common are Ploceus cucullatus (Becker and Diallo, 1992). In our survey, factors noted by farmers as affecting the extent of bird damage are sowing date, type of variety, plant architecture, whether the panicle has awns, date of maturity, and season of the year. Farmers noted the advantage of some of the traditional varieties which have "droopy" panicles, which do not allow the birds to alight easily, and awned panicles which help to deter attack. To scare birds, farmers may use indigenous mud slings (Kpavou) made from pliable sticks with depressions at one end, which allow hardened soil plugs to be flung some distance toward feeding birds. Other methods to scare birds include the use of catapults, the tying of tin cans to long strings which can be swung in the air to create a loud noise, and the placing of dummies in fields. In the forest zone, farmers cited the use of some wild plants "Neninkro" or "Nokônokô" (Momordica charantia), for the control of birds. The dry leaves of these plants are crushed and the resulting powder is scattered on the rice plants. Farmers considered this lethal for birds provided certain rituals are obeyed, the most important being that the person that applies these herbs must be the last to leave the field.

\subsubsection{Rodents}

Our survey indicated that rodent problems are most common in the forest and forestsavannah zones, with $88 \%$ and $87 \%$ of farmers citing them as serious problems, compared with only $2 \%$ of farmers in the savannah (Table 2). Becker and Diallo (1992) also found that farmers cited rodents as important pests of rice in the more humid zones. Rodent species ranked as most abundant in the Becker and Diallo study included the grasscutter (Thyonymys swinderianus), western striped ground squirrel (Xerus erythropus), pygmy mouse (Mus minutoides), multi-mammate rat (Mastomys erythroleucus), roof rat (Rattus rattus), and the 
Nile Rat (Arvicanthis niloticus). Several control methods are used, including fencing of rice fields (i.e., "palisades") against grasscutters, usually with Raphia fronds (Raphia gigantea) and stems of Pennisetum purpureum. In the forest zone, where rice is essentially a woman's crop among the Béte tribe, the major rice-cultivating activity of men, at times the only one, is to assist women in the construction of these "palisades." Fencing entails such considerable labor in searching for materials, cutting, collecting, and constructing the fences, that when fields are large, farmers often cannot provide complete coverage. Other control methods include locally made traps, using children to dig up the nests where the rats live, setting fire to the surrounding fields to chase rodents from their dwellings and killing them with hunting dogs or guns. No farmer reported using poison, probably because of cost and because rodents are eaten by farmers or sold as "bush meat."

While vertebrate pests have been reported as major pests of rice in Asia (Heong, 1984) and West Africa (Funmilayo and Akande, 1985; Arraudeau and Harahap, 1986; Goldman, 1987; Becker and Diallo, 1992), they have been ignored in most IPM programs. In Nigeria it was estimated that vertebrate pests (i.e., birds and rats) cause up to $40 \%$ of preharvest losses (Funmilayo and Akande, 1985), and certainly farmers in our survey accorded these pests a high degree of importance. This emphasis of most integrated pest control programs on arthropod pests has been criticized (Goldman, 1987).

\subsection{Insect pests}

\subsubsection{Type of insects}

While most farmers were aware that insects constitute a limiting factor in rice production, only 80 farmers ( $45 \%$ ) were able to specifically identify the insects that damage rice in the field. ${ }^{3}$ Some farmers noticed the occurrence of "white heads" (unfilled panicles caused by stem borer feeding) on rice fields but did not know what caused the problem. Some farmers associated the occurrence and intensity of whiteheads to rainfall deficits, since drought at the time of grain filling can also cause whiteheads, which can easily be confused with those caused by the feeding of stem-borers.

Leaf-feeding insects were reported by both upland and lowland farmers (Table 5). In the uplands, $54 \%$ of respondents in this ecosystem cited leaf-feeding insects, mostly beetles such as Chaetocnema spp. and Chnootriba similis whose presence is easily detected. Leaffeeders were also often reported as pests in the traditional lowlands (i.e., inland valleys). In the Ivory Coast, the case worm Nymphula depunctalis and the hispid beetle Trichispa sericea are abundant in fields with standing water. Termites occur under only upland conditions and were reported as important by $46 \%$ of the upland farmers. In improved lowland systems with water control, farmers reported stem-borers as important pests. The stemborers consist of a number of species, including the striped borer Chilo zacconius, Scirpophaga sp., pink stem-borer Sesamia calamistis, and the diopsid flies Diopsis apicalis and D. macrophthalma. It is of interest to note that no farmer cited stem-borers as pests in upland fields whereas $79 \%$ of respondents cited stem-borers in improved lowlands. Field surveys by Agyen-Sampong (1982), however, indicate that stem-borers can also be pests under upland conditions. Studies in the Ivory Coast indicate that stem-borers cause yield losses reaching $42 \%$ in experimental plots of upland rice (WARDA, 1988). Only one farmer 
mentioned the African rice gall midge Orseolia oryzwora. This may be because of low levels of damage or an inability to associate plant damage with the pest. The adult midges are very small and difficult to see and the onion leaf-like galls of infested tillers tend not to be associated by farmers with insect attack. This is supported by our direct field observations in the humid-forest zone where we observed one farmer who experienced almost $100 \%$ crop damage but could not identify the causal agent of the rice plant damage, which we identified as gall midge attack. While it has been documented that the gall midge is very damaging on farmers' fields in Nigeria (Ukwungwu and Joshi, 1992), the extent of damage in the Ivory Coast is as yet unknown.

Table 5. Number (percentage) of responding farmers $(N=80)$ in each rice agro-ecosystem who cited various types of insect pests as being problematic, Ivory Coast, 1992

\begin{tabular}{lcccc}
\hline & \multicolumn{4}{c}{ Rice agro-ecosystem } \\
\cline { 2 - 5 } No. of respondents: & $\begin{array}{c}\text { Uplands } \\
(n=39)\end{array}$ & $\begin{array}{c}\text { Improved } \text { lowlands } \\
(n=28)\end{array}$ & $\begin{array}{c}\text { Traditional b lowlands } \\
(n=13)\end{array}$ & $\begin{array}{c}\text { Total } \\
(N=80)\end{array}$ \\
\hline Insect pests & & & & \\
Termites & 18 & - & - & 18 \\
& $(46)$ & $(0)$ & 10 & $(23)$ \\
Leaf-feeders & 21 & 5 & $(77)$ & 36 \\
& $(54)$ & $(18)$ & 3 & $(45)$ \\
Stem-borers & - & 22 & $(23)$ & 25 \\
& $(0)$ & $(79)$ & - & $(31)$ \\
Gall midge & - & 1 & $(0)$ & 1 \\
& $(0)$ & $(3)$ & $(1)$ \\
\hline
\end{tabular}

a. Lowlands where farmers use bunds and canals for water control. Because of better control of water in these systems, they are categorized as improved lowlands. The source of water is from diversion from streams or from dams.

b. Lowlands with rudimentary dikes and bunds or flooded inland valleys with no water control structures. Usually farmers do not have good water control in these lowlands.

\subsubsection{Farmers' perception of losses from insect pests}

Farmers expect some losses from pests and may sustain certain levels of crop losses without considering them economically significant (Goldman, 1987). When asked to evaluate whether insects cause damage to their rice fields $44 \%$ of the total sample farmers said that insects do. However, farmers' perceptions of the intensity of the losses caused by insects is highly variable. Of the farmers indicating insects as causing yield loss, $16 \%$ felt that the extent of losses are "important" or "very important," $21 \%$ indicated that they were of "minor importance" and 63\% felt the extent of losses are "not important." When asked to indicate the frequency of insect losses experienced over the last 10 years, 79\% of the farmers were not able to respond. For the farmers that responded, their estimates ranged from "no losses in the last 10-year period" (11 farmers), "losses in two out of the last 10 years" (8 farmers), "once in the last 10-year period" (5 farmers), "losses in 3-5 years out of the last 10 years" (12 farmers), and "experienced losses every year" (2 farmers). 


\subsubsection{Farmers' perceptions of factors causing an increase in insect pest problems}

Farmers suggested a range of factors they believed contributed to insect problems on their rice fields. Among these were soil type and fertility, presence of standing water, high relative humidity, drought, type of forest vegetation, presence of weeds, and presence of termite hills. A number of these factors are related. For example, termites are found on upland fields, and farmers indicate that their occurrence increases with drought. Certain insects such as the caseworm (Nymphula depunctalis), leaf miner (Trichispa sericea) and the African rice gall midge (Orseolia oryzivora) are associated with standing water. Certain weeds also provide habitats for various insect pests of rice. Further work is now under way at WARDA to define the insect/weed/natural enemy interactions and explore how farmers perceive these interactions to help direct further IPM research.

\subsubsection{Periods when insect pests are problematic}

Farmers were asked to indicate periods during the cropping season when insect problems become most serious. Of the total number of farmers surveyed only $46 \%$ were able to indicate the period. While it appears that insect pests occur during all stages of crop growth, the most critical periods according to farmers are 60 days after sowing (D.A.S.) (19\% of farmers), at germination (13\%), 30 D.A.S. (12\%), and 90 D.A.S. (12\%).

\subsubsection{Control practices}

3.3.5.1. Traditional practices. While farmers are able to predict the occurrence of insect pest problems to some extent, the development of indigenous cultural control tactics for insects is very limited. Among the indigenous control methods cited were the random throwing of lemons on the fields (thought to create an odor that repels insects), pouring of hot water on, or physical destruction of, termite hills, throwing of palm leaves on the fields, and use of traditional herbalists ("feticheurs").

3.3.5.2. Chemical control methods. Farmers were asked if they used insecticides for the control of field insect pests in rice. Only 29 farmers (or 16\% of the total number) responded positively. However, the extent of use varies considerably across rice ecosystems (Table 6). The number of farmers using insecticides is highest in improved lowland rice ecosystems. While $50 \%$ of all farmers cultivating improved lowland ecosystems used insecticides, $21 \%$ of the traditional lowland farmers and only $6 \%$ of farmers growing upland rice used insecticides.

Across agro-ecological zones, more farmers use insecticides on rice in the forest-savannah zone $(30 \%)$ than in the other two study zones $(13 \%$ and $5 \%$ in the forest and savannah zones respectively). Seventy-five percent of farmers using insecticides applied them only once per crop while $20 \%$ applied them two or more times. 
Table 6. Number of rice farmers using insecticides in each agro-ecological zone and rice agroecosystem, Ivory Coast, 1992

\begin{tabular}{lcccc}
\hline & \multicolumn{4}{c}{ Agro-ecological zone } \\
\cline { 2 - 5 } Rice agro-ecosystem & Humid-forest & Forest-savannah & Savannah & Percent \\
\hline Upland rice $(N=117)$ & 1 & 6 & - & 6 \\
Improved lowlands $(N=32)$ & 4 & 11 & 1 & 50 \\
Traditional lowlands $(N=29)$ & 3 & 1 & 2 & - \\
Percentage of farmers in zone & 13 & 30 & 5 & \\
$\quad$ using insecticides & & 36 & \\
Percentage of all farmers & & & \\
$\quad$ cultivating lowlands across all & & & \\
$\quad$ zones using insecticides & & & \\
$\quad \begin{array}{l}\text { Percentage of all farmers } \\
\text { cultivating uplands across all } \\
\text { zones using insecticides }\end{array}$ & & & \\
\hline
\end{tabular}

Farmers reported the use of insecticides on other crops, and on cash crops in particular; $38 \%$ of farmers had used insecticides on cotton, while $10 \%$ of farmers reported the use of insecticides on tree crops (i.e., cocoa and coffee). The wider use of insecticides on cotton is due in part to the availability of subsidized credit facilities with the cotton development agency. And, because cotton is grown solely as a cash crop farmers are more willing to purchase inputs to avoid potentially high losses. It has been argued by other authors that farmers pay relatively little attention to pests when they attack subsistence crops, but that when the crop is destined for the market they are less willing to tolerate damage (Conelly, 1987; Goldman, 1987).

\subsection{Diseases}

Farmers did not regard rice diseases as being a serious problem. This may signify that under the current nonintensive rice systems, losses from diseases are very limited or, more likely, that the losses that do occur are incorrectly diagnosed. In one example, where we observed serious infestation of rice blast (Pyricularia oryzae), the farmer suggested that this was caused by soil infertility rather than disease. Other farmers noted the presence of spots or lesions on the leaves but indicated that they did not notice any important impact on yields. The low level of importance attached to rice diseases has also been observed in studies in Asia, with farmers tending to recognize only those pests that they can see (Litsinger et al., 1982; Heong and Ho, 1987). Observations in the Ivory Coast show that diseases cause significant yield losses on research stations, but the economic importance of losses on farmers' fields remains unclear.

Bentley (1992) reported that farmers in Honduras had a poor classification of bean diseases and tended to group together fungal diseases with viral infections, nutrient deficiencies, and other factors. Furthermore, it was suggested that farmers' knowledge could be characterized along two axes describing the importance and ease of observation of the pest phenomena, with important and easily observed factors tending to be well understood and classified, while factors that were unimportant and difficult to observe, tend to be poorly understood. With respect to this survey the question is raised as to whether those pest 
problems which were important and easy to observe (i.e., weeds, rodents, and birds) received an exaggerated response and ranking compared with those pest problems which were difficult to observe. Some insect problems, diseases, and certainly nematodes would correspond to the difficult-to-observe category and therefore may not have been associated accurately with yield losses.

\section{Discussion}

While weeds are considered as the major pest in all agro-ecological zones, the importance of other pest groups varies across zones. Birds, rodents, and insects are considered as relatively more important in the humid-forest and forest-savannah zones; diseases, while of low importance across all zones, were accredited with relatively greater importance in the humid-forest zone. It is likely, however, that the relatively low importance attached to diseases may reflect the difficulty farmers face in separating disease damage from those of other environmental stresses such as drought, soil nutrient deficiencies, and soil toxicities.

Farmers identify a range of weed species and recognize those which are becoming more serious over time. In the humid-forest and forest-savannah zones, the use of long fallow periods is the principal weed management strategy used by farmers cultivating uplands and undeveloped lowlands. Where this fails, high weed infestations often cause farmers to abandon their fields, at least in part. With the increasing pressure on land and resultant declines in fallow periods, such situations will increase in frequency unless more effective alternative weed management strategies are adopted. The weeds which farmers identify as becoming increasingly serious are likely to be those caused by intensification of cultivation. Further studies, with farms or study areas selected on the basis of cultivation intensity, will help to clarify the relationship between intensification and weed flora. The list of principal weeds cited by farmers was, understandably, shorter than lists developed by scientists. This reflects the importance that farmers place on a limited number of weeds rather than the wider range which are of interest to scientists, and as such it may be a valuable guide to more clearly focus research strategies.

Farmers indicate that the importance of insects pests is dependent on the rice ecosystem. In general, insects were noted by farmers as causing most severe losses in the lowlands where stem-borers and leaf-feeders were the major concern. Termites are regarded as a problem in the upland areas, particularly when rainfall is lacking. These observations are in agreement with research findings. The ranking of important pests by farmers raises a number of questions for researchers, including how significant are the actual losses caused by pests, do they correctly attribute them to a particular pest, and are the losses attributed to insect pests and diseases underestimated? Certainly, the relative difficulty in observing the cause and effects of insect and disease damage makes the latter appear quite likely. If this is the case, it seems unlikely that farmers would adopt technologies to control such pests unless the advantages of these can be more clearly demonstrated.

Rice is cultivated in the Ivory Coast mainly by subsistence farmers who have low incomes and use minimal external chemical inputs. The majority of farmers are not contacted by extension agents; and even for irrigated lowland farmers who previously had good contacts with the state rice development agencies, the recent disengagement of the state 
from rice production has led to an abrupt rupture in these linkages. With these limitations, it is essential that pest management practices developed for these farmers build on their knowledge of pests and the existing traditional pest management practices. In particular, integrated pest management technologies should involve: (1) development of technologies that maintain the existing high biodiversity of natural enemies in the rice ecosystems, (2) improvement of existing cultural control practices, and (3) development of pest-resistant rice varieties. The latter would include the development of rice cultivars that are able to compete with, or tolerate, weed competition as well as having durable host plant resistance to the major insect pests and diseases. All these efforts should involve incremental changes in the pest management practices of farmers, build on their managerial abilities, and involve significant farmer participation in technology development and testing. To achieve this, a major reorientation of research toward on-farm studies may be required to determine research priorities in common with those of the farmer.

The survey indicates that insect and disease problems in traditional low-input systems do not appear to be severe. However, it is likely that, as has already been observed in Asia, as intensification of rice production occurs and farmers use increasing amounts of external inputs, pest populations could increase to damaging levels. This could be especially relevant in lowland ecosystems where sustainable intensification of rice production is most feasible. Effective integrated pest management systems are therefore most important for this ecosystem if its production potential is to be achieved.

Finally, current IPM research by rice scientists in the Ivory Coast, and indeed in West Africa more generally, do not include vertebrate pests, while farmers' evaluations indicate that these pests are in fact more important than the conventionally accepted pest components (i.e., insects and diseases) in IPM strategies. It is strongly recommended that specific efforts be made to develop control tactics and technologies for vertebrate pests. A possible first step is to determine the species composition of rodent populations and assess the levels of yield losses in farmers' fields. If losses are high and support the importance attached to these pests by farmers, it may be necessary to explore the effectiveness of breeding to incorporate traits such as strong and stiff stems in improved varieties in order to reduce susceptibility to rodent damage. Evidence from rodent damage studies in other parts of the world suggest that rodents have preferences for rice varieties with stems that are easier to cut (Khokhar and Rizvi, 1991) and that varieties with strong and stiff stems suffer relatively less rodent damage (Chaudry and Rehman, 1986). With respect to birds, farmers noted the distinct advantage of traditional varieties with awns and "droopy panicles" to minimize bird damage. The potential of breeding to incorporate such traits into improved lines should be evaluated.

Acknowledgments - We thank Peter Mallon, C. Riches, S. Eden-Green, D. J. Robison, A. RussellSmith, L. Shaxson, and M. Webb for helpful comments, and Moustapha Gaye for assistance in data processing and analysis. We thank our field assistants Sandje Sele, Bamba Adama, Seydou Sere, and Moriba Doumbia, who worked under difficult conditions in the field. We are grateful to Roger Diallo for clarifications provided. Finally, we are indebted to the rice farmers for sharing their time and knowledge with us. 


\section{Notes}

1. The work of D. E. Johnson was commissioned by the UK Overseas Development Administration through the Natural Resources Institute, Chatham, UK.

2. These are multiple responses and therefore the percentages do not add up to $100 \%$.

3. Farmers gave descriptions of the insects and the damage they cause, and also showed them to us in their fields. we then identified the insect species.

\section{References}

Agyen-Sampong, M., 1982. Les principaux depredateurs des ecosystemes de riziculture irriguee, pluviale et de mangrove dans les zones climatiques des regions Tropicales, Humides, de la Savane Guineenne, et du Sahel. In Gestion Integree des Depredateurs du Riz en Afrique l'Ouest (Bouaké, Ivory Coast: West Africa Rice Development Association), pp. 346-359.

Akobundu, I. O. and Fagade, S. O., 1978. Weed problems of African rice lands. In I. W. Buddenhagen and G. J. Persley (eds.) Rice in Africa (London: Academic Press), pp. 181-192.

Arraudeau, M. and Harahap, Z., 1986. Relevant upland rice breeding objectives. In Progress in Upland Rice Research (Manila, Philippines: International Rice Research Institute), pp. 189-197.

Atteh, O. D., 1984. Nigerian farmers perception of pests and pesticides. Insect Science and Its Application, 5(3), 213-220.

Becker, L. and Diallo, R., 1992. A Classificacion of Rice-Growing Agro-ecosystems of Côte d'Ivoire (Bouaké, Côte d'Ivoire: West Africa Rice Development Association), 353 pp.

Bentley, J. W. 1992. The epistemology of plant protection: Honduran campesino knowledge of pests and natural enemies. In R. W. Gibson and A. Sweetmore (eds.) Proceedings of a Seminar on Crop Protection for Resource-Poor Farmers (Copenhagen: Technical Centre for Agricultural and Rural Cooperation/Natural Resources Institute), pp. 107-118.

Chaudry, A. M. and Rheman, H., 1986. Basmati-385: a new variety for Punjab. Progressive Farming, 6, 25-30.

Conelly, W. T., 1987. Perceplions and management of crop pests among subsistence farmers in South Nyanza, Kenya. In J. Tait and B. Napompeth (eds.) Management of Pests and Pesticides: Farmers' Perceptions and Practices (Boulder and London: Westview Press), pp. 198-209.

Delabarre, M., 1977. Incidence Agronomique du Développement de Eupatorium odoratum (composée) en Côte d'Ivoire. Doctoral thesis, l'Université Nationale de Côte d'Ivoire, 108 pp.

Diallo, R., 1981. La culture du soja en Côte d'Ivoire (Abidjan: Ministère de l'Agriculture) (mimeograph), $76 \mathrm{pp}$.

Funmilayo, O. and Akande, M., 1985. Estimated crop and cash losses caused by vertebrate pest damage to rice in Western Nigeria. Nigerian Agriculture Journal, 19/20, 94-101.

Girard, G., Sircoulin, J. and Touchbeut, P., 1971. Aperçu sur les régimes hydroliques. In Le Milieu Natural de la Côte d'Ivoire. Memoires ORSTOM No. 50, Paris, pp. 113-151.

Goldman, A. C., 1987. Agricultural pests and the farming system: a study of pest hazards and pest management by small scale farmers in Kenya. In J. Tait and B. Napompeth (eds.) Management of Pests and Pesticides: Farmers' Perceptions and Practices (Boulder and London: Westview Press), pp. 117-131.

Heong, K. L., 1984. Pest control practices of rice farmers in Tanjung Karang, Malaysia. Insect Science and Its Application, 5(3), 221-226. 
Heong, K. L. and Ho, N. K., 1987. Farmer perceptions of the rice tungro virus problem in the Muda Irrigation Scheme, Malaysia. In J. Tait and B. Napompeth (eds.) Management of Pests and Pesticides: Farmers' Perceptions and Practices (Boulder and London: Westview Press), pp. 165-172.

Hussein, M. Y., 1987. Perception and management of pests by Malaysian traditional small farmers: a case study. In J. Tait and B. Napompeth (eds.) Management of Pests and Pesticides: Farmers' Perceptions and Practices (Boulder and London: Westview Press), pp. 142-149.

Kenmore, P. E., Litsinger, J. A, Bandong, J, P., Santiago, A. A. and Salac, M. M., 1987. Philippine rice farmers and insecticides: thirty years of growing dependency and new options for change. In J. Tail and B. Napompeth (eds.) Management of Pests and Pesticides: Farmers' Perceptions and Practices (Boulder and London: Westview Press), pp. 98-108.

Khokhar, A. R. and Rizvi, S. W. A., 1991. A survey of rodent damage and yield loss in Basmati-385, a new rice variety in Punjab, Pakistan. Journal of Plant Protection in the Tropics, 8(1), 47-53.

Litsinger, J. A., Canapi, B. and Alviola, A., 1982. Farmer perceptions and control of rice pests in Solana, Cagayan valley, a pre-green revolution area of the Philippines, Philippine Entomologist, 5, 373-383.

Marnotte, P., 1984. Upland rice weed problems in Côte d'Ivoire. In An Overview of Upland Rice Research. Proceedings of the 1982 Bouaké, Côte d'Ivoire, Upland Rice Workshop (Los Baños, Philippines: International Rice Research Institute), pp. 343-353.

Merlier, M., 1974. Végétation Adventice des Rizières Pluviales de Côte d'Ivoire. In Deuxième Symposium sur le Désherbage des Cultures Tropicals (Montpellier, France: Columa/Gerdat), pp. 127-141.

Mumford, J. D. and Norton, G. A., 1984. Economics of decision making in pest management. Annual Review of Entomology, 29, 157-174.

Prah, K. K. and Okeyo, A. P., 1989. The role of social science in generating technologies for the farming community in Africa. Insect Science and Its Application, 10(6), 777-782.

Riches, C. R., 1992. The Striga problem on rice in Côte d'Ivoire. Project A0214 (Chatham, UK: Natural Resources Institute) (mimeograph), $15 \mathrm{pp}$.

Riches, C. R., Shaxson, L. J., Logan, J. W. M. and Munthali, D. C., 1993. Insect and parasitic weed problems in Southern Malawi and the use of farmer knowledge in the design of control measures. Paper presented at the conference on Agricultural Research for Development held at Mangochi, Malawi, 7-11 June, 15 pp.

Rouw, A. de, 1991. Rice weeds and shifting cultivation in a tropical rain forest. A study of vegetation dynamics. Doctoral thesis, Agricultural University, Wageningen, 263 pp.

Schulten, G. M., 1989. The role of FAO in IPM in Africa. Insect Science and Its Application, 10(6), 795807.

Tait, J. and Napompeth, B. (eds.), 1987. Management of Pests and Pesticides: Farmers' Perceptions and Practices (Boulder and London: Westview Press), $225 \mathrm{pp}$.

Ukwungwu, M. N. and Joshi, R. C., 1992. Distribution of Africa Rice Gall Midge, Orseolia oryzivora Harris and Gagne and its parasitoids in Nigeria. Tropical Pest Management, 38(3), 241-244.

Warda, 1988. Annual Report for 1988 of West Africa Rice Development Association (Bouaké, Ivory Coast: WARDA), 48 pp.

Warren, D. M. 1989. Linking scientific and indigenous agricultural systems. In J. Lin Compton (ed.) The Transformation of International Agricultural Research and Development (Boulder and London: Lynne Rienners), pp. 153-170.

Zethner, O. (ed), 1989. Pest Management and the African Farmer. Proceedings of the ICIPE/World Bank conference held in Nairobi, Kenya, 22-26 May 1989. 